\title{
ELEMENTY STYLIZACJI BRZMIENIOWEJ W SERIALU TELEWIZYJNYM RANCZO
}

\author{
SŁOWA KLUCZOWE: STYLIZACJA BRZMIENIOWA, KOLOKWIALIZACJA, DIALEKTYZACJA
}

\section{WSTĘP}

Stylizacja językowa była dotychczas badana głównie jako element towarzyszący tworzeniu tekstów literackich, które poddawano analizie właśnie pod jej kątem. Celem poniższego artykułu jest zbadanie języka wybranych bohaterów serialu Ranczo w kontekście zastosowanej w nim stylizacji brzmieniowej. Występują w nim dwa rodzaje tej stylizacji - kolokwializacja i dialektyzacja.

W poniższym artykule opisałam procesy i zjawiska fonetyczne w mowie wybranych bohaterów przywoływanego serialu. Postanowiłam zbadać zjawiska charakterystyczne dla mowy potocznej. Ograniczyłam się jednak do tych realizacji fonetycznych, które znajdują się w obrębie normy użytkowej polszczyzny lub wykraczają poza nią. Zwracałam uwagę na te cechy, które są swego rodzaju niedociągnięciami artykulacyjnymi lub po prostu błędami w wymowie. Stąd też wybór bohaterów, w których języku występuje wiele cech niezgodnych z normą wzorcową. Są nimi: Patryk Pietrek (Piotr Pręgowski), Maciej Solejuk (Sylwester Maciejewski), Hadziuk (Bogdan Kalus), Stach Japycz (Franciszek Pieczka) i Solejukowa (Katarzyna Żak). Poza elementami charakterystycznymi dla mowy potocznej zbadałam także wszystkie zjawiska stanowiące reprezentację odmiany gwarowej polszczyzny. Było to nieuniknione ze względu na pochodzenie postaci serialu, które są przedstawicielami ludności wiejskiej. To właśnie cechy dialektalne pojawiające się w ich języku stanowią ogromną część stylizacji brzmieniowej wykorzystanej w serialu i powodują, iż widz, oglądając serial, od razu identyfikuje bohaterów z przedstawicielami określonej warstwy społecznej i klasyfikuje ich jako mieszkańców wsi. 
Materiał badawczy zbierałam od lipca do grudnia 2015 r. Wszystkie wyodrębnione przykłady pochodzą z różnych sezonów Rancza (od pierwszego do dziewiątego). Materiał podzieliłam ze względu na zjawiska językowe, które dany przykład unaoczniał. Przy każdym z nich znalazła się także informacja dotycząca bohatera, u którego dana cecha wystąpiła. Wszystkie były także sygnowane numerem sezonu, z którego zostały zaczerpnięte. Do tego celu stworzyłam skrót Se. oznaczający sezon.

Ranczo to komediowa opowieść o losach młodej Amerykanki Lucy Wilskiej. Bohaterka odziedziczyła we wsi Wilkowyje dworek, w którym postanawia zamieszkać. Przenosi się z Nowego Jorku do Polski i próbuje odnaleźć się w zupełnie innym dla siebie świecie. Stara się cywilizować wieś i jej mieszkańców (m.in. walcząc z alkoholizmem i przemocą w rodzinach). Próby reformowania wsi i obyczajów, utrwalonych przez lata, nie przysparzają jej przyjaciół. Wielokrotnie musi toczyć boje z przesądami, stereotypami, a nawet władzą wójta Pawła Kozioła. Ostatecznie po kilku latach udaje jej się zdobyć powszechny szacunek i zaufanie, dzięki czemu obejmuje posadę wójta gminy Wilkowyje.

Tematem artykułu jest stylizacja językowa w serialu Ranczo. Pojęcie stylizacji językowej definiuje A. Markowski w Wielkim stowniku poprawnej polszczyzny. Określa on to zjawisko jako ,świadome kształtowanie tekstu jakiejś wypowiedzi zgodnie z normami stylistycznymi charakterystycznymi dla innego typu wypowiedzi" [Markowski 2004: 1677]. Jest to zatem zastosowanie takich środków językowych, które będą charakterystyczne dla innego stylu niż ten, którym posługuje się twórca danego tekstu. Obejmuje elementy wszystkich warstw językowych (fonetyki, fleksji, słowotwórstwa, leksyki czy składni). Może być realizowana na przestrzeni całego tekstu lub tylko jego części (np. w powieści w dialogach bohaterów). Stylizacja językowa służy uwiarygodnieniu przekazu. W serialu Ranczo zabieg ten ma spowodować, że odbiorca będzie identyfikował bohaterów jako mieszkańców wsi. Markowski opisuje trzy najczęściej występujące rodzaje stylizacji językowej - archaizację, kolokwializację oraz dialektyzację (stylizację gwarową). W zebranym materiale mamy do czynienia z dwiema ostatnimi.

Kolokwializacja jest wprowadzaniem do tekstu elementów odmiany potocznej języka (takich jak kolokwializmy, wulgaryzmy, anakoluty). Może być fragmentaryczna lub całościowa. Wyrazistym przykładem tej stylizacji jest głośna powieść Doroty Masłowskiej Wojna polsko-ruska pod flaga biało-czerwona.

Kolejnym typem stylizacji językowej jest dialektyzacja, inaczej stylizacja gwarowa. Jest to wprowadzenie do tekstu elementów gwary ludowej. Występuje często w tekstach ukazujących środowisko wiejskie. Autor może stylizować język bohaterów na konkretną gwarę, jednak wtedy powinien stosować wyłącznie zjawiska obecne w tej właśnie gwarze czy dialekcie i unikać pomyłek (np. stosowania mazurzenia w stylizacji na gwary wielkopolskie). Innym rodzajem dialektyzacji jest stylizacja na tzw. język chłopski, w której chodzi jedynie o stworzenie wrażenia mowy gwarowej. Ten właśnie rodzaj występuje w serialu Ranczo. Bohaterowie stosują cechy językowe z różnych gwar, co nie przeszkadza odbiorcy utożsamiać ich z mieszkańcami wsi. 
Z kolei samo zjawisko stylizacji brzmieniowej zdefiniowała A. Okopień-Sławińska. Określa ona ten rodzaj stylizacji jako ,imitowanie za pomocą celowego ukształtowania brzmieniowego wypowiedzi jakości brzmieniowych charakterystycznych dla jakichś innych wypowiedzi" [Okopień-Sławińska 2008: 540]. W serialu Ranczo występuje stylizacja brzmieniowa wykorzystująca zarówno osobliwości gwarowe, jak i cechy języka potocznego.

Jeśli chodzi o dialektyzację, to w przypadku Rancza jest ona bardziej intuicyjna niż poparta wiedzą naukową autora scenariusza. Jest to przykład konstruowania wypowiedzi, których cechy nie są charakterystyczne dla jednej konkretnej gwary ludowej, a zawierają elementy różnych dialektów, dzięki czemu odbiorca ma wrażenie słuchania języka mieszkańców wsi. Tak jak już wcześniej wspomniałam, przeciętny odbiorca nie zna dobrze różnic między cechami dialektalnymi i potrzebuje tylko pewnego zarysu, sygnału, by móc „przyporządkować” bohatera do danej grupy społecznej. Zastosowane są więc zjawiska charakterystyczne dla różnych dialektów (mazowieckiego, wielkopolskiego czy obszaru Kresów Wschodnich). Nie przeszkadza to jednak w odbiorze wypowiedzi jako tekstu gwarowego.

W materiale badawczym w obrębie stylizacji na język potoczny znalazły się uproszczenia artykulacyjne oraz rozłożenie samogłoski nosowej $q \mathrm{w}$ wygłosie.

\section{UPROSZCZENIA ARTYKULACYJNE W OBRĘBIE SPÓEGLOSEK I GLOSEK PRZEJŚCIOWYCH}

Uproszczenia artykulacyjne stanowią jedną z najbardziej powszechnych cech mowy potocznej, z różnych przyczyn. Mogą one wynikać z tempa mówienia (szybszego, niż np. w wystąpieniach publicznych), niedbałości o precyzyjną wymowę, braku świadomości językowej mówiących, ale przede wszystkim z potrzeby ułatwienia sobie procesu mówienia podyktowanej wygodą językową, choć może to prowadzić do zakłócenia odbioru wypowiedzi. W zebranym przeze mnie materiale da się wyróżnić kilka rodzajów uproszczeń artykulacyjnych.

\subsection{UPROSZCZENIA GRUP SPÓŁGLOSKOWYCH}

Grupy spółgłoskowe przysparzają aparatowi mowy wielu trudności, zwłaszcza połączenia spółgłosek o różnym miejscu artykulacji czy stopniu otwarcia narządów. Dlatego też w niektórych sytuacjach upraszczamy sobie tę wymowę poprzez wyeliminowanie pewnych głosek lub ich przekształcenie. Bardzo wyraźnie widać to w stylizacji zastosowanej przez aktorów Rancza. Oto przykłady uproszczeń grup spółgłoskowych:

a) w nagłosie

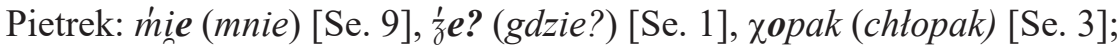

Solejukowa: a mui $\frac{1}{\mathfrak{e}} \boldsymbol{e}$ ? (gdzie?) [Se. 9];

Solejuk: abo (albo) [Se. 1];

Hadziuk: mie (mnie) [Se. 2]. 
b) w śródgłosie

Pietrek: fryssko (wszystko) [Se. 3];

Solejuk: vínencuaski (Więctawski) [Se. 1];

Hadziuk: pośl'iznouem śe (poślizgnątem się) [Se. 1], inednoska (jednostka) [Se. 1].

c) w wygłosie

Pietrek: taka je uńía (taka jest unia) [Se. 5], nik ńe vine (nikt nie wie) [Se. 4];

Solejuk: pšestempčoś (przestępczość) [Se. 1].

\subsection{ZANIK SPÓŁGEOSKI W WYGEOSIE}

Kolejną zaobserwowaną przeze mnie cechą jest zanik spółgłoski, najczęściej bezdźwięcznej, w wygłosie. Taka wymowa wynika najczęściej z niedbałości nadawcy o wybrzmienie końcowych elementów wyrazu. Takie zjawisko występuje na terenie całej Polski w odmianie potocznej języka. Nie wynika ono z trudności wymówienia danej spółgłoski, a raczej z lenistwa mówiącego. W serialu cecha ta jest realizowana w następujących przykładach:

Pietrek: mamy co? (coś) [Se. 2], tera (teraz) [Se. 9].

Drugi przykład powtarza się w wypowiedziach tej postaci trzykrotnie. Jest to wymowa, którą możemy usłyszeć na terenie całej Polski, jednak Kucała [Kucała 1994: 100] kwalifikuje ją w swojej pracy jako cechę poznańską.

Solejuk: zara pov́e (zaraz powie) [Se. 1], pšeće (przecież) [Se. 1], tera (teraz) [Se. 9].

Stach Japycz: pšyńeś co (przynieś coś) [Se. 3].

Solejukowa: ina inuš otpokutowaua (ja już odpokutowatam) [Se. 4], ta (tak) [Se. 5];

Hadziuk: cud inak'i spravii (cud jakiś sprawi) [Se. 1], zara (zaraz) [Se. 1], viiżiš tam

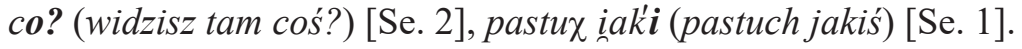

\subsection{ZANIK GLOSKI MIĘDZY SAMOGLOSKAMI}

a) ńe milaeś gadać?(nie miałeś gadać?) [Pietrek Se. 9], uratovaeś (uratowateś) [Hadziuk Se. 2] - dochodzi tu do pominięcia (,połknięcia”) głoski przejściowej (półotwartej) u, które znacznie ułatwia wymowę (zwłaszcza w szybkim tempie). Aparat mowy musi jedynie nieznacznie podwyższyć artykulację niskiego $a$ do średniego $e$, co jest łatwiejsze niż wymówienie dodatkowo rozdzielającego ich $u$, które artykułuje się prawie w tym samym miejscu, co samogłoski ustne, ale zwężenie narządów mowy jest przy nim większe.

b) W zebranym materiale występują też przykłady usunięcia innych spółgłosek rozdzielających samogłoski $a$ i $e-\check{c} \breve{s} e a(t r z e b a)$ [Pietrek Se. 3] oraz dvaeśća ( $d w a-$ dzieścia) [Solejukowa Se. 5]. Dochodzi do nich z podobnych przyczyn - łatwiej wymówić obok siebie dwie samogłoski niż dodatkowo rozdzielać je dźwięcznymi spółgłoskami. 


\section{ROZŁOŻENIE SAMOGŁOSKI NOSOWEJ $Q$ W WYGLOSIE}

Wymowa samogłosek nosowych przysparza Polakom wielu trudności. Tutaj zajmę się wyłącznie wygłosową samogłoską $q$, której wymowa przez aktorów świadczy najsilniej o stylizacji językowej na język potoczny. W polszczyźnie ogólnej należy ją artykułować z pełną nosowością. Rozłożenie jej w wygłosie na samogłoskę ustną i spółgłoskę nosową jest według normy, zarówno wzorcowej jak i użytkowej, niedopuszczalne i „dyskwalifikuje wszystkich użytkowników języka, w tym zwłaszcza osoby publiczne" [Karpowicz 2009: 38]. Obecnie ta cecha staje się niemal powszechną cechą wymowy. W serialu samogłoski nosowe są realizowane przede wszystkim beznosówkowo (co wykażę poniżej), jednak udało mi się zgromadzić kilka przykładów omawianej powyżej konsonantycznej realizacji tylnej samogłoski nosowej:

takom [Pietrek Se. 1], viizom [Selejuk Se. 1], rozumiom [Piertek Se. 1], ṕišom [Solejuk Se. 3], znainom [Hadziuk Se. 4].

Omówiona powyżej kolokwializacja nie wyczerpuje znamion stylizacji brzmieniowej zaobserwowanej w mowie bohaterów Rancza.

Kolejnym jej przejawem jest stylizacja gwarowa - dialektyzacja. Dialektyzacja zastosowana w serialu Ranczo łączy w sobie istotne cechy różnych dialektów: małopolskiego, mazowieckiego i wielkopolskiego, takie jak: beznosówkowa wymowa, przejście $\mathrm{o} \geq \mathrm{u}$, przejście $\mathrm{e} \geq \mathrm{y}$ oraz $\mathrm{e} \geq \mathrm{i}$, twarda wymowa spółgłoski $l$ po miękkiej, miękka wymowa spółgłosek $k, g, \chi$ przed samogłoską $e$ czy wymowa $\breve{o}$ przedniojęzykowo-zębowego.

\section{BEZNOSÓWKOWA WYMOWA}

Realizacja samogłosek nosowych w polskich dialektach zasadniczo różni się od tej obowiązującej w polszczyźnie ogólnej. Beznosówkowa wymowa jest cechą charakterystyczną dla dialektu małopolskiego. Jest to jedyny dialekt, w którym dochodzi do pełnej denazalizacji nosówek we wszystkich pozycjach. Taka właśnie wymowa jest charakterystyczna dla każdego z bohaterów serialu, których język zbadałam. Warto zauważyć, że jest to cecha, która niemal od razu sygnalizuje widzowi pochodzenie postaci jako mieszkańców wsi. Uwidacznia się ona w następujących przykładach:

a) wymowa samogłoski $q$ :

w mowie bohaterów serialu pojawia się przede wszystkim odnosowienie w wygłosie, jednak występują także pojedyncze przekłady denazalizacji samogłoski $q$ w śródgłosie przed szczelinową twardą, np.:

Hadziuk: sṕiskuio [Se.5], bedo [Se. 5], iak s to tarčo [Se. 5], samo roboto žyl’i [Se. 4], inag z gorončko [Se. 4], ziezo [Se. 1], vínezo [Se. 1], trave žro [Se. 1], znaidde novo babe i lepšo i muotšo [Se. 1], iedno mamy [Se. 1], davno by io zamknel'i [Se. 1];

Solejukowa: za roboto [Se. 9], rosno [Se. 9], obiady smakuio [Se. 9], novo kśoške [Se. 5], za íedno noc [Se. 5], s pšyiemnośćo [Se. 5], fkrencai o [Se. 4].

Solejuk: oddazo [Se. 9], pomyślo to vymyślo [Se.9], śćigaino [Se. 4], ze sobo [Se. 2]. 
Pietrek: įako pšygode [Se. 4], každo puščo [Se. 9], ze mno [Se. 9], maio [Se. 9], орхоzо [Se. 5], puaco [Se. 5], zagrańično [Se. 4], naše so [Se. 4], íak to muv́io [Se. 4];

Stach Japycz: stoino i śe gaṕio [Se. 3].

b) wymowa samogłoski ę jako e (wraz z pominięciem następnej głoski) jest realizowana przede wszystkim w różnych formach czasownika być, np. be ż $\boldsymbol{e}$ [Pietrek Se. 9], na viečur bede [Pietrek Se. 3], be źe ći io [Solejuk Se. 1], ńe bede [Solejukowa Se. 9] lub žeńić be žíěs śe? [Hadziuk, Se. 9]. Warto zwrócić uwagę na to, że taka denazalizacja samogłoski ę w śródgłosie i pominiecie spółgłoski w formach fleksyjnych czasownika „być” są charakterystyczne także dla mowy potocznej.

\section{PrzejŚ́cie o $\geq \mathrm{U}$}

Podwyższenie artykulacji o $\geq \mathrm{u}$ jest związane $\mathrm{z}$ kontynuantami staropolskiego $\dot{p}$ długiego. Według Dejny, na terenie Małopolski i Mazowsza nastąpiło „zwężenie, cofnięcie i zaokrąglenie artykulacji $\dot{o}$ powodujące przejście pochylonego $\dot{o}$ w u" [Dejna 1981: mapa 61B]. Taka właśnie wymowa występuje u bohaterów badanego przeze mnie serialu. Najczęściej pojawia się ona u Pietrka, ale sporadycznie także u innych bohaterów.

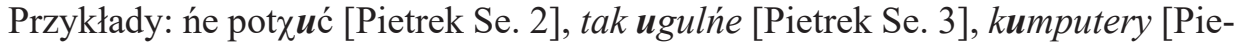
trek Se. 9], dyrektur [Pietrek Se. 9], a na cu? [Solejukowa Se. 5], ńe vźuu [Pietrek Se. 4], uny (w znaczeniu oni) [Solejuk Se. 5], ty kunuśí [Solejukowa Se. 4].

\section{PrzeJŚCIE E $\geq$ Y ORAZ E $\geq$ I}

Podwyższenie artykulacji e $\geq$ y lub e $\geq$ i związane jest $\mathrm{z}$ kontynuantami staropolskiego $\varepsilon$ długiego. Dejna wyróżnia kilka rodzajów realizacji tej samogłoski. W serialu pojawia się wymowa charakterystyczna dla terenów ciągnących się od południowego wschodu $\mathrm{w}$ kierunku północno-zachodnim, czyli podwyższenie artykulacji e $\geq$ y po twardej i e $\geq$ i po miękkiej. Tę wymowę realizują bohaterowie Rancza. Oto świadczące o tym przykłady:

a) przejście e $\geq y$

ienčyć [Pietrek Se. 5], iedyn [Solejukowa Se. 4], zalynguo [Solejuk Se. 1].

Występują także przykłady przejścia grupy e $i \geq \mathrm{y} n$. prenzy (zamiast prenzei) [Solejuk Se. 1], ve fspulny spraviie (zamiast $f_{\text {spulnei) }}$ [Stach Japycz Se. 3], do vuasny baby (zamiast vuasnei ) [Hadziuk Se. 1], inačy (zamiast inačei ) [Solejukowa Se. 1].

b) przejście $\hat{\mathrm{e}} \geq \mathrm{i}$

Pietrek: ńi volno [Se. 2], a toki co? [Se. 2], zapaminintaua [Se. 3], ṕińienze [Se. 3],

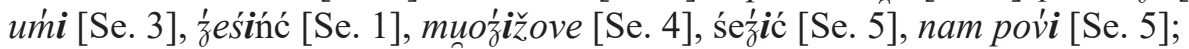

Hadziuk: leṕii ńiž pomńik [Se. 3], ṕińonz [Se. 1], ambasady amerykańsk'ii [Se. 1], guośniii [Se. 1], umi [Se. 9].

Solejukowa: mńe poví [Se. 3], fčeśńii [Se. 1], žyća ńi mamy [Se. 1], do śekii [Se. 4], pretensini (w znaczeniu: pretensien) [Se. 4], ńe pov́im [Se. 4], z̛iń dobry [Se. 5];

W serialu wielokrotnie pojawia się także słowo kokita. To również przykład kontynuantów $\varepsilon$ długiego, jednak według Kucały [Kucała 1994: 9-10] jest to forma często występująca $\mathrm{w}$ odmianie potocznej polszczyzny ogólnej. 


\section{TWARDA WYMOWA SPÓŁgŁOSKI $L$ PO MIĘKKIEJ}

Wymowa typu lys, lypa, malyna występuje na terenie Mazowsza. Jest związana z rozwojem staropolskiego $l$ '. W dialekcie mazowieckim doszło do stwardnienia $l$ ' nawet przed i [zob. Dejna 1981: mapa 16B]. Jest to wymowa odbiegająca od polszczyzny ogólnej, w której zmiękczamy $l$, jeśli występuje przed samogłoską $i$ (np. l'is, l'ipa, mal'ina). Nieliczne przykłady tej cechy dialektu mazowieckiego występują w badanym przeze mnie serialu:

zamyślyuam śe [Solejukowa Se. 9], ńe vynaleźly [Japycz Se. 3], ńeščeślyvy [Pietrek Se. 1].

\section{MięKKa WYMOWa SPÓlgloseK $K, G$, $\chi$ PRZed SAMOgloską $E$}

Tego typu wymowa występuje u dwojga bohaterów serialu: Pietrka i Solejukowej. Według Kucały jest to cecha charakterystyczna dla terenów Mazowsza i Pomorza „częściowo przemieszana z twardym ke, ge” [Kucała 1994: 32]. W serialu pojawia się stosunkowo rzadko (9 przykładów). Mazowiecka twarda wymowa zamiast poprawnej zmiękczonej (jak w języku ogólnopolskim) występuje w moim materiale tylko raz: inakeś zamiast íakięeś [Pietrek Se. 3]. Stanowi to przykład braku tzw. IV polskiej palatalizacji. Poniżej przedstawiam przykłady wymowy podanej w podtytule:

Solejukowa: g̉ieny [Se. 3], moğie [Se. 9], troskịe [Se. 9], val'iskị e [Se. 9].

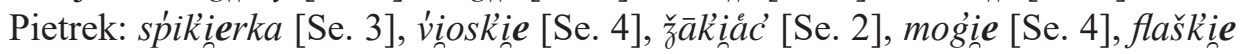
[Se. 9].

Język bohaterów serialu dostarcza również przykładów charakterystycznego dla dialektu mazowieckiego zmiękczenia i przejścia grupy $\chi y \geq \dot{\chi} i$. Postanowiłam omówić je tutaj ze względu na niewielką liczbę przykładów oraz charakter zbliżony do wyżej omawianej wymowy.

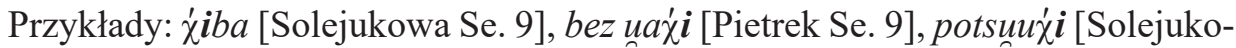
wa Se. 3], ג'ikiu [Solejukowa Se. 9].

\section{WYMOWA $\breve{~ P R Z E D N I O J E ̨ Z Y K O W O-Z E ̨ B O W E G O ~}$}

Wymowa $\breve{~ p r z e d n i o j e ̨ z y k o w o-z e ̨ b o w e g o ~ t o ~ o b e c n i e ~ c e c h a ~ c h a r a k t e r y s t y c z n a ~ d l a ~}$ obszaru Kresów Wschodnich. We współczesnej polszczyźnie słyszana jest jeszcze u osób starszych. W serialu Ranczo osobą, u której spotykamy tę wymowę, jest Stach Japycz grany przez Franciszka Pieczkę. W przypadku aktora nie jest to jednak stylizacja językowa ani cecha wynikająca z pochodzenia ${ }^{1}$. Wymowa $\breve{o}$ przedniojęzykowo-zębowego była dawniej wymagana od studentów w szkole aktorskiej. Franciszek Pieczka wymawia $\breve{o}$ także w innych swoich rolach (np. w filmie Konopielka). Warto zaznaczyć, że Stach jest jedyną postacią serialu, u której ta wymowa występuje regularnie i jest bardzo wyraźnie słyszalna. Świadczą o tym poniższe przykłady:

${ }^{1}$ Aktor urodził się na Śląsku, gdzie ta cecha nie występuje. 
staŏo [Se. 5], sktućiŏy śe [Se. 5], zaхçaŏo śe [Se. 5], pasowaŏo [Se. 4], vrućiŏo śe [Se. 4], gŏova [Se. 3], osŏab'íona [Se. 3], byŏa [Se. 3], podešŏa [Se. 3], pan vŏaza

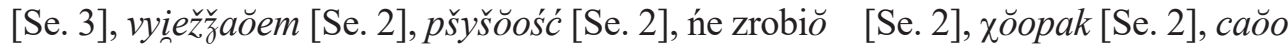
[Se. 2].

Z moich badań wysnułam kilka wniosków. Po pierwsze, występowanie w Ran$c z u$ wszystkich badanych przeze mnie zjawisk jest wynikiem stosowania przez aktorów zabiegu stylizacji językowej. Świadczy o tym fakt, iż aktorzy na co dzień (np. w wywiadach telewizyjnych) posługują się zupełnie innym językiem. Większość z nich dba o poprawność językową, również w zakresie fonetyki. Świadectwem opisywanej stylizacji brzmieniowej na język potoczny są liczne w mowie bohaterów uproszczenia artykulacyjne oraz nienormatywna wymowa samogłosek nosowych. Jeśli chodzi o dialektyzację, to o jej stosowaniu świadczy fakt, iż żaden aktor, którego język badałam, nie pochodzi z terenów wiejskich i na co dzień nie posługuje się gwarą. Ponadto pewne zjawiska zaobserwowane w mowie aktorów są zapisane w scenariuszu i stanowią podpowiedź scenarzysty ${ }^{2}$, jak należy wymawiać dane wyrazy, by lepiej odzwierciedlić język ludności wiejskiej. Po drugie cechy fonetyczne bohaterów nie są konsekwentne. Wyjątek stanowi wymowa $\breve{o ~ p r z e d n i o j e ̨ z y k o w o-~}$ -zębowego u Stacha Japycza granego przez aktora starszego pokolenia Franciszka Pieczkę. Niektórzy bohaterowie w początkowych sezonach wykorzystywali pewne cechy, które zaniknęly w dalszych odsłonach serialu (np. rozłożenie nosówki w wygłosie, stosowane kilkakrotnie w sezonach 1-4, które w dalszych częściach zostało w pełni zastąpione przez beznosówkową wymowę). Jeśli chodzi o dialektyzację, to mamy tu do czynienia z tzw. stylizacją na język chłopski, stąd przenikanie się cech różnych dialektów. Niewielu badaczy zajmuje się natomiast stylizacją brzmieniową w filmach czy serialach, stąd też pomysł na ten artykuł. Na zakończenie pragnę zauważyć, że w dotychczasowych opracowaniach dialektyzację fonetyczną bada się najczęściej na materiale utworów literackich, natomiast zjawisko to zastosowane w serialach jest wciąż niezbadane i otwiera szerokie perspektywy badawcze.

${ }^{2}$ Otrzymałam scenariusze czterech odcinków serialu [Se. 8] dzięki uprzejmości producenta (StudioA) oraz scenarzysty Roberta Bruttera. Zawierają one wskazówki dotyczące m.in. beznosówkowej wymowy czy grupy,$y \geq-i$. Oto wybrany fragment: DOM WOJTA. SALON. DZIEŃ. Cd psychoterapii, acz nietypowy, bo rozpętała się pyskówka między Hadziukową i Solejukową zjednej strony, a małżonkami z drugiej. Klaudia śledzi to, cokolwiek zszokowana.

SOLEJUKOWA: A przyjdzie nabąblowany po pachi, jak snopek na łóżko zwali się i chrapie! Ot, głowa rodziny!

HADZIUKOWA: A ty pilnuj jeszcze, żeby petem niezgaszonym domu nie podpalił! I tyle z niego pożytku! Mąż to się nazywa!

HADZIUK: A by w domu co miłego czekało, to by i człowiek znieczulać nie musiał się!

SOLEJUK: Tak jest! Choćby i najtrzeźwiejszy przyszedł i tak wiadomo, że łeb suszyć będzie! To głupi na trzeźwo by sie narażał! 


\section{BibLIOGRAFIA}

Dejna K. [1981], Atlas polskich innowacji dialektalnych, PWN, Warszawa-Lódź.

Karpowicz T. [2009], Kultura języka polskiego. Wymowa, ortografia, interpunkcja, Wydawnictwo Naukowe PWN, Warszawa.

Kucała M., [1994], Twoja mowa cię zdradza. Regionalizmy i dialektyzmy języka polskiego, Biblioteczka Towarzystwa Miłośników Języka Polskiego nr 22, Kraków.

Okopień-Sławińska A. [2005], Stylizacja brzmieniowa, [w:] Słownik terminów literackich, Sławiński J.(red.), Ossolineum, Wrocław-Warszawa-Kraków, wyd. piąte b.z., s. 540.

Wielki stownik poprawnej polszczyzny PWN [2004], Markowski A. (red.), Warszawa. 